University of Chicago Law School

Chicago Unbound

\title{
Corporate Reorganizations and the Treatment of Diverse Ownership Interests: A Comment on Adequate Protection of Secured Creditors in Bankruptcy
}

\author{
Douglas G. Baird \\ Thomas H. Jackson
}

Follow this and additional works at: https://chicagounbound.uchicago.edu/journal_articles

Part of the Law Commons

\section{Recommended Citation \\ Douglas G. Baird \& Thomas H. Jackson, "Corporate Reorganizations and the Treatment of Diverse Ownership Interests: A Comment on Adequate Protection of Secured Creditors in Bankruptcy," 51 University of Chicago Law Review 97 (1984).}

This Article is brought to you for free and open access by the Faculty Scholarship at Chicago Unbound. It has been accepted for inclusion in Journal Articles by an authorized administrator of Chicago Unbound. For more information, please contact unbound@law.uchicago.edu. 


\title{
Corporate Reorganizations and the Treatment of Diverse Ownership Interests: A Comment on Adequate Protection of Secured Creditors in Bankruptcy
}

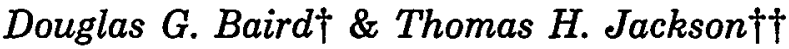

Bankruptcy law does not exist in a vacuum, yet one cannot spend much time reading in the field without noting that few judges or scholars have taken this observation to heart. ${ }^{1}$ Too many seem to think that a bankruptcy proceeding provides, in the main, an essentially unlimited opportunity to do what appears at the moment to be good, just, or fair without regard to the reasons for having a system of bankruptcy laws in the first place. ${ }^{2} \mathrm{~A}$ close study of the present controversy over the adequate protection of secured creditors illustrates the shallowness of much of the recent discussion of bankruptcy law and the consequences of a failure to

$\dagger$ Professor of Law, University of Chicago.

†† Professor of Law, Stanford University. We would like to thank Walter Blum, Frank Easterbrook, and Mark Roe for helpful comments on an earlier draft. Robert Rasmussen provided valuable research assistance. This research was supported in part by the Stanford Legal Research Fund, made possible by a bequest from the estate of Ira S. Lillick and by gifts from other friends of Stanford Law School.

1 Many of the judges who have taken the observation to heart have been those who are not immersed on a daily basis in bankruptcy law, and who therefore have some perspective. See, e.g., Butner v. United States, 440 U.S. 48, 56 (1979) (criticizing use of "undefined considerations of equity" to change result dictated by nonbankruptcy law in bankruptcy); In re Applied Logic Corp., 576 F.2d 952, 957 (2d Cir. 1978) (Friendly, J.) (criticizing bankruptcy judge's reliance on a "dominant impulse[]" of bankruptcy towards "equality among creditors" when dealing with a statutory section "the dominant impulse' of which is inequality among creditors" and noting that the rule (allowing setoffs) "is not one that courts are free to ignore when they think application would be 'unjust" ").

See Bank of Marin v. England, 385 U.S. 99, 103 (1966) ("There is an overriding consideration that equitable principles govern the exercise of bankruptcy jurisdiction."); In re Booth, 19 Bankr. 53, 58 (Bankr. D. Utah 1982) (recharacterizing a contract for deed as a lien "because treatment of the contract for deed as a lien enlarges the value of the estate and furthers the rehabilitation of the debtor"). Courts on occasion state that, in bankruptcy, "equality is equity." See, e.g., Canright v. General Fin. Corp., 35 F. Supp. 841, 844 (E.D. Ill. 1940). See generally Festersen, Equitable Powers in Bankruptcy Rehabilitation: Protection of the Debtor and the Doomsday Principle, 46 AM. BANKR. L.J. 311, 317 (1972) ("[C]ourts are becoming more . . . disposed to exercise their discretionary powers in favor of debtors and, accordingly, more forthright about doing so."). The slogan may have some meaning when applied to parties who have the same substantive rights under nonbankruptcy law, but it quickly loses its focus otherwise. 
view bankruptcy as serving a unique, but limited, function in our society. ${ }^{3}$

The filing of a bankruptcy petition automatically stays creditors from repossessing property of the debtor in which they have a security interest. These creditors, however, can demand that the stay be lifted unless their interests in the debtor's property are "adequately protected." As a matter of statutory illustration, adequate protection is the granting of relief that "will result in the realization by [the holder of the interest] of the indubitable equivalent of such entity's interest in such property." ${ }^{\circ}$ In the context of secured credit, the need for adequate protection, according to the legislative history of the Bankruptcy Code, rests "as much on policy grounds as on constitutional grounds. Secured creditors should not be deprived of the benefit of their bargain."

However clear and simple this statutory command may appear, it has nevertheless come under attack from two distinct directions. Professor Rogers has asserted in a recent article that Congress has given secured creditors too much protection in bankruptcy because it erroneously thought the fifth amendment constrained it from limiting the rights of secured creditors (and presumably others). ${ }^{8}$ Bankruptcy judges, moreover, have been asserting with growing frequency that adequate protection for a secured creditor whose collateral is left in the estate during the

s For a discussion of other examples of the failure to take a broader view of bankruptcy, see Eisenberg, Bankruptcy Law in Perspective, 28 UCLA L. Rzv. 953, 959-76 (1981); Jackson, Avoiding Powers in Bankruptcy, 36 STAN. L. REv. (1984) (forthcoming) [hereinafter cited as Jackson, Avoiding Powers]; Jackson, Bankruptcy, Non-Bankruptcy Entitlements, and the Creditors' Bargain, 91 YALE L.J. 857, 883-87 (1982) [hereinafter cited as Jackson, Non-Bankruptcy Entitlements].

11 U.S.C. $\$ 362$ (a) (1982) imposes the automatic stay.

- Section 362(d)(1) of the Bankruptcy Code, 11 U.S.C. § 362(d)(1) (1982), expresses the adequate protection rule as follows:

On request of a party in interest and after notice and a hearing, the court shall grant relief from the stay provided under subsection (a) of this section, such as by terminating, annulling, modifying, or conditioning such stay-(1) for cause, including the lack of adequate protection of an interest in property of such party in interest ....

- 11 U.S.C. § 361(3) (1982). But see In re Alyucan Interstate Corp., 12 Bankr. 803, 809 (Bankr. D. Utah 1981) ("Indubitable equivalence is not a method; nor does it have substantive content. . . . At best, it is a semantic substitute for adequate protection and one with dubious, not indubitable, application to the question of relief from the stay.").

7 S. REP. No. 989, 95th Cong., 2d Sess. 53 (1978), reprinted in 1978 U.S. CodE Cong. \& AD. News 5787, 5839 [hereinafter cited as SENate ReporT]; H.R. REP. No. 595, 95th Cong., 1st Sess. 339 (1977), reprinted in 1978 U.S. CodE CoNG. \& AD. NEws 5963, 6295 [hereinafter cited as House REPORT].

- Rogers, The Impairment of Secured Creditors' Rights in Reorganization: A Study of the Relationship Between the Fifth Amendment and the Bankruptcy Clause, 96 HaRv. L. REv. 973, 977-97 (1983). 
pendency of the bankruptcy proceeding does not include compensation for the "time value" of their secured claims, but only the cost of physical depreciation ${ }^{9}-$ a conclusion with which Professor Rogers and others have concurred. ${ }^{10}$ These judges and commentators have assumed both that a central goal of bankruptcy law, embodied in its reorganization provisions, ${ }^{11}$ is to help firms in financial straits stay in business and that limiting the rights of secured creditors in this way advances this goal without significantly undercutting any other worthwhile policies.

As others have shown, however, an interpretation of the Bankruptcy Code that denies creditors compensation for the time value of their secured claims is, as a matter of statutory construction, strained, if not clearly wrong. ${ }^{12}$ As interesting an inquiry, to which we turn in this article, is whether those who want to limit the rights of secured creditors are correct as a matter of what bankruptcy law should be. This normative inquiry must begin with critical questions about why a bankruptcy process exists at all-questions that simple statements about the purposes of bankruptcy law do not answer. Consider the "rehabilitation" goal of a Chapter 11 proceeding. ${ }^{13}$ No one, to our knowledge, argues that

\footnotetext{
- See, e.g., In re American Mariner Indus., 27 Bankr. 1004, 1010 (9th Cir. Bankr. App.) (adequate protection can usually be accomplished by paying depreciation), appeal docketed, No. 83-5806 (9th Cir. 1983); In re South Village, Inc., 25 Bankr. 987, 990 n.3, 1002 (Bankr. D. Utah 1982) (same); In re Pine Lake Village Apartment Co., 19 Bankr. 819, 824 (Bankr. S.D.N.Y. 1982) (same); In re Nixon Machinery Co., 9 Bankr. 316, 317-18 (Bankr. E.D. Tenn. 1981) (same); In re Bermec, No. 71-8-291 (Ref. S.D.N.Y.) (same under old Bankruptcy Act), aff'd, 445 F.2d 367 (2d Cir. 1971); cf. In re C.F. Simonin's Sons, Inc., 28 Bankr. 707, 713 (Bankr. E.D.N.C. 1983) ("While protection for lost opportunity costs for going concern values may not be required in cases with a high chance of success, liquidation values, including lost opportunity costs, must be protected in cases where the chance of reorganization is slight.").

However, some courts (including most Article III courts) have recognized that the failure to compensate for time value results in a substantial diminution of the secured creditor's interest in the collateral. See, e.g., In re Monroe Park, 17 Bankr. 934, 940 (D. Del. 1982); In re Virginia Foundry Co., 9 Bankr. 493, $497-98$ (W.D. Va. 1981); In re Anchorage Boat Sales, Inc., 4 Bankr. 635, 643 (Bankr. E.D.N.Y. 1980); see also In re Schaller, 27 Bankr. 959, 960-62 (W.D. Wis. 1983) (granting relief from the automatic stay because debtor's assets were insufficient to pay interest on debt during the period of the reorganization).

10 See Rogers, supra note 8, at 996; see also 2 Collier on Bankruptcy $\uparrow 362.01$, at 362.13 (15th ed. 1983); O'Toole, Adequate Protection and Postpetition Interest in Chapter 11 Proceedings, 56 Am. Bankr. L.J. 251, 251-52 (1982).

"Chapter 11 contains the core of the Bankruptcy Code's reorganization provisions. See 11 U.S.C. $\$ \S 1101-1174$ (1982).

12 For a lucid discussion of the mandates of the Bankruptcy Code, see Comment, Compensation for Time Value as Part of Adequate Protection During the Automatic Stay in Bankruptcy, 50 U. CHI. L. REv. 305, 309-22 (1983).

1s See, e.g., NLRB v. Bildisco \& Bildisco, 104 S. Ct. 1188, 1197 (1984); United States v.
} 
keeping a firm intact is always a good thing. Yet as soon as one concedes that a reorganization may not always be desirable, one is faced with the problem of understanding and articulating why reorganizations are favored in the first place and how much should be given up to facilitate them. Similarly, the observation that Congress, at least if it acted prospectively, could deny secured creditors compensation for the time value of their claims does little more than rebut an argument of almost no constitutional currency. ${ }^{14}$ Indeed, Congress, acting prospectively, probably could refuse to recognize the rights of secured creditors altogether. But to say this much is not to say that Congress should refuse to recognize those rights or that it should refuse to recognize them only in bankruptcy.

In this article, we suggest that bankruptcy law at its core should be designed to keep individual actions against assets, taken to preserve the position of one investor or another, from interfering with the use of those assets favored by the investors as a group. ${ }^{16}$ Arguments over the wisdom of many substantive rules are not arguments about the way to implement this goal, and it misperceives the inquiry to focus on the wisdom of such rules as a matter of bankruptcy policy. Bankruptcy law should change a substantive nonbankruptcy rule only when doing so preserves the value of assets for the group of investors holding rights in them. For this reason, bankruptcy law necessarily overrides the remedies of individual investors outside of bankruptcy, for those "grab" rules

Whiting Pools, Inc., 103 S. Ct. 2309, 2312 (1983).

14 Neither Congress nor the Supreme Court saw a constitutional barrier to enacting a provision of the Bankruptcy Code prospectively limiting the rights of lenders holding nonpurchase-money security interests in a debtor's household goods. See 11 U.S.C. § 522(f) (1982); United States v. Security Indus. Bank, 103 S. Ct. 407, 414 (1982). Congress also curtails certain rights of secured creditors under its other powers (such as the commerce clause). Cf. 15 U.S.C. $\$ \S 1671-76$ (1982) (sections of the Consumer Credit Protection Act restricting wage garnishments). In the face of this evidence, it seems difficult to believe that, acting prospectively at least, Congress has felt unduly constrained by the fifth amendment.

10 By "investor" (or "owner"), we mean anyone with rights, however contingent, to the debtor's assets under nonbankruptcy law. By "rights," we mean the right to the income stream generated by the firm's assets, the right to receive payment out of the assets, or the right to the assets upon dissolution. "Rights," so used, is not the same as "interests" as used in 11 U.S.C. $\S 361$ (1982) (defining adequate protection) and 11 U.S.C. $\S 362$ (d) (1982) (grounds on which court may grant relief from the automatic stay). Those with rights include not only secured creditors, but also, for example, shareholders, who, like other investors, have a right to the firm's assets (subject to the rights of creditors). The creation of "rights" as we speak of them here, moreover, may be voluntary, as in the case of shareholders, bondholders, or trade creditors, or involuntary, as in the case of tort victims and the government (in its capacity as tax collector). 
undermine the very advantages sought in a collective proceeding. ${ }^{16}$ Changes in substantive rules unrelated to preserving assets for the collective good of the investor group, however, run counter to the goals of bankruptcy. Such rule changes in bankruptcy can induce an individual investor to seek bankruptcy merely to gain access to rule changes that offer him benefits, regardless of whether there are any benefits-or indeed costs-to the investor group as a whole.

Based upon this view of bankruptcy law, we examine the protection afforded to secured creditors in bankruptcy, asking, first, what exactly the secured creditors' nonbankruptcy rights are and, second, whether any modification of those rights is necessary in order to preserve or enhance the firm's assets for the general benefit of the investor group. What these nonbankruptcy rights should be is a question that is unrelated to whether they should be followed in bankruptcy. We show that protecting the value of a secured creditor's nonbankruptcy rights-whatever they might be-actually reinforces the bankruptcy policy of putting the firm's assets to their best use by placing the costs of trying to keep the assets of a firm together on those who stand to benefit from such an effort. If these parties do not bear these costs, they will have an incentive to place a firm in bankruptcy and to draw out the proceeding, even though doing so does not work to the advantage of those with rights to the firm's assets when their interests are considered as a group.

\section{The Problem of Drverse Ownership Interests}

Those who have argued that secured creditors should not be given the full value of their rights under state law in bankruptcy often also argue that a bankruptcy proceeding must respond to the greater social problems that attend a business failure. ${ }^{17}$ The failure of a firm affects many who do not, under current law, have cognizable ownership interests in the firm outside of bankruptcy. The economy of an entire town can be disrupted when a large factory closes. Many employees may be put out of work. The failure of one firm may lead to the failure of those who supplied it with raw materials and those who acquired its finished products. ${ }^{18}$ Some be-

16 See Jackson, Non-Bankruptcy Entitlements, supra note 3, at 862 .

${ }_{17}$ See, e.g., In re South Village, Inc., 25 Bankr. 987, 995 (Bankr. D. Utah 1982) (discussing the legislative history of 11 U.S.C. $\$ 361$ (1982)); Rogers, supra note 8, at 1001-05.

18 See P. Coleman, Debtors and Creditors in America: Insolvency, Imprisonmznt POR DEBT, AND BANKRUPTCY, 1607-1900, at 13 (1974) (Legislators "knew that the failure of a 
lieve that preventing such consequences is worth the costs of trying to keep the firm running and justifies placing burdens on a firm's secured creditors. ${ }^{19}$

We think that this view is, as a matter of bankruptcy policy, fundamentally wrong. Fashioning remedies for all the harm a failing business may bring is difficult and beyond the competence of a bankruptcy court. The wider effects of the failure of a particular enterprise are not easy to assess. A principal characteristic of a market economy is, after all, that some firms fail, and postponing the inevitable or keeping marginal firms alive may do more harm than good. ${ }^{20}$ Forcing investors to keep assets in a relatively unproductive enterprise may limit the freedom of the same or different investors to use those assets in a different and more productive one. Keeping a firm in one town from closing may have the indirect effect of keeping a new one in a different town from opening. Moreover, limiting the ability of investors to reclaim their assets may reduce their incentive to invest (rather than consume) in the first instance. Instead of weighing these effects equally, a bankruptcy judge is likely to focus on the demonstrable harms of those who are before him.

But there is a more important reason for denying a bankruptcy judge broad license to protect people in the wake of economic misfortune. The problems brought by business failures are not bankruptcy problems. A bankruptcy proceeding should not be the place to implement a policy that society does not enforce outside of bankruptcy and that is unrelated to the preservation of assets for the firm's investor group. Most businesses fail without a bankruptcy petition ever being filed. If it is a bad policy to protect secured creditors in full while workers remain unpaid, it should not matter whether a bankruptcy petition has been filed. So, too, if a secured creditor should properly share with everyone else in the

single merchant or planter sometimes brought a chain reaction of insolvencies."); cf. REPORT of the Commission on the BankRuptcy Laws of the UntTEd States (pt. 1), H.R. Doc. No. 137, 93d Cong., 1st Sess. 71 (1973) ("The primary function of the bankruptcy system is to continue the law-based orderliness of the open credit economy in the event of a debtor's inability . . to pay his debts.").

19 See, e.g., In re Bermec Corp., 445 F.2d 367, 369 (2d Cir. 1971) ("We are conscious of the deep concern of the manufacturing secured creditors lest their security depreciate beyond adequate salvage, but we must balance that with the Congressional mandate to encourage attempts at corporate reorganization where there is a reasonable possibility of success.").

${ }^{20}$ The decision to liquidate, in other words, generates externalities, but these externalities may be both positive and negative. See generally J. Dukeminier \& J. KRIER, ProperTy 52-57 (1981). 
economic misfortunes of a debtor, he should be required to carry his share of the loss in every instance, not just in the minority of cases in which a bankruptcy petition is filed.

Nonbankruptcy concerns, we believe, should not be addressed by changing bankruptcy policy. Our view derives from two related observations: first, that bankruptcy law is, and should be, concerned with the interests of those (from bondholders to unpaid workers to tort victims to shareholders) who, outside of bankruptcy, have property rights in the assets of the firm filing a petition, and, second, that in analyzing the interests of these parties with property rights, our baseline should be applicable nonbankruptcy law. A collective insolvency proceeding is directed toward reducing the costs associated with diverse ownership interests and encouraging those with interests in a firm's assets to put those assets to the use the group as a whole would favor.

Other problems should be addressed as general problems, not as bankruptcy problems. Social reform should be brought about through broad changes in the substantive law rather than through ad hoc modifications of rights in bankruptcy. Such comprehensive reform ensures that like cases are treated alike and makes clearer the rights of all players, who, before the fact, do not know whether a bankruptcy petition will be filed. If it is important, for example, that ailing firms stay in business to preserve existing jobs, then their obligation to do so should derive from substantive law, not from a special bankruptcy rule. A firm should not be able to avoid the obligation to take into account the jobs of employees simply by dissolving under state law or otherwise remaining outside bankruptcy. Conversely, the substantive rights of owners (be they large financial lenders, asbestosis victims, or shareholders) should not turn on whether a debtor files a bankruptcy petition, dissolves under state law, or remains in business. Protecting the victims of economic misfortune who have not been given rights against assets may be an important social and legal question, but it is not, at present, a concern of substantive nonbankruptcy law, and is not, therefore, properly a bankruptcy question either. The way in which that question is resolved should not turn on whether a bankruptcy proceeding is commenced. Thus, bankruptcy law should focus only on the interests of those who, outside of bankruptcy, have property rights in the assets of the firm.

Just as the filing of a petition in bankruptcy provides little justification for altering the relative rights of owners and non-owners of the firm, so should it have little effect on the rights of own- 
ers inter se. ${ }^{21}$ Changes in nonbankruptcy rights should be made only if they benefit all those with interests in the firm as a group. A rule change unrelated to the goals of bankruptcy creates incentives for particular holders of rights in assets to resort to bankruptcy in order to gain, for themselves, the advantages of that rule change, even though a bankruptcy proceeding was not in the collective interest of the investor group. ${ }^{22}$ Moreover, as we develop below, once a bankruptcy proceeding begins, the change in nonbankruptcy rights impedes collective decisionmaking by the investor group about the deployment of the firm's assets. ${ }^{23}$

When a firm files a petition in bankruptcy, two questions arise. First, one must decide what to do with the firm's assets, and, second, because of the presence of diverse owners, one must decide who gets them. Our principal proposition is that the answer to the second question should not, ideally, alter the answer to the first. Consider the case where only one person has all the rights to the firm's assets. Such a person, the sole owner of the assets, would have no creditors, consensual or otherwise; no one but he would have a right to use those assets. Irrespective of any thought of bankruptcy, this sole owner would continually reevaluate his use of the assets. He might decide to sell the assets piece by piece. Alternatively, he might decide to keep the assets together (along with the firm's accumulated good will and expertise). In the latter event, he would still need to decide whether to keep running the business himself or to sell it as a unit to a third party. He would be utterly indifferent to bankruptcy policy because, unless his firm's use of it benefitted him (by permitting his firm, for example, to escape a nonbankruptcy charge), ${ }^{24}$ he would have no occasion to

21 Jackson, Non-Bankruptcy Entitlements, supra note 3, at 871-72.

${ }^{22}$ This phenomenon-often called "misbehavior"-exists whenever rights are fixed by contract and then, after the contract is entered into, circumstances permit one side to profit by welching on the contract. See R. Posner, Economic Analysis of Law 293-94 (2d ed. 1977); Jensen \& Meckling, Theory of the Firm: Managerial Behavior, Agency Costs and Ownership Structure, 3 J. Fin. Econ. 305, 312-15 (1976).

${ }^{23}$ For example, assume that a firm's assets are worth $\$ 100,000$ if sold for scrap, but $\$ 96,000$ if continued in the business, and that a secured creditor has a state-law right to $\$ 50,000$ of these assets. If the unsecured creditors are able, in a reorganization, to give the secured creditor a package of rights that, because it did not recognize the time value of money, was worth less than $\$ 46,000$, they would have an incentive to reorganize the firm's business (where they would capture more than $\$ 50,000$ in value), even though the optimal decision for the creditors as a group would probably have been to liquidate it. See Jackson, Non-Bankruptcy Entitlements, supra note 3, at 862.

3 Bankruptcy law, for example, sometimes permits the rejection of collective bargaining agreements that could not be rejected under applicable nonbankruptcy law. See NLRB v. Bildisco \& Bildisco, 104 S. Ct. 1188, 1194-97 (1984). But cf. In re Tinti Constr. Co., 29 
use the bankruptcy process. ${ }^{25}$ If a charge were placed upon assets only in bankruptcy law (such as that a firm could not go out of business without first protecting employees), this owner would remain free to ignore it by going out of business outside of bankruptcy. He could only be obligated to take account of such a charge if it were imposed by nonbankruptcy law. Because a sole owner has no distributional decision to make, his only concern is the best deployment of the assets.

The unique function of a bankruptcy system comes into sharp focus when the situation of the sole owner, who does not need bankruptcy and can ignore its policies, is compared to that of diverse owners. Bankruptcy law is fundamentally a collective proceeding $^{26}$ and as such, is needed only when there is no such sole owner of the firm's assets. When the "rights"27 to the assets are spread among more than one person, as they almost always are, ${ }^{28}$ someone must decide not only how best to deploy the assets, but also how to split up the returns from those assets. ${ }^{29}$ The answer to this second question, however, should not affect the determination of how to deploy the assets. As a group, these diverse owners-bondholders, tort victims, trade creditors, shareholders, and others-would want to follow the same course as a sole owner. The

Bankr. 971, 974-75 (Bankr. E.D. Wis. 1983) (improper to use bankruptcy solely for purpose of rejecting collective bargaining agreement).

${ }_{25}$ The availability of discharge is irrelevant in the present example because there are no competing claims to the assets. Bankruptcy's discharge policy and corporate reorganizations are discussed further infra note 45 .

16 Jackson, Non-Bankruptcy Entitlements, supra note 3, at 859-71.

27 See supra note 15.

2s It is, of course, commonplace for the owners of an entity to have diverse interests. The principal distinction, under state law, among the "owners" of a firm is that some are paid ahead of others. Bondholders and other secured creditors are paid before debenture holders and other general creditors, such as trade creditors and tort claimants. They in turn are paid before preferred shareholders, who are paid before common shareholders. These various groups of owners are alike in that all have some sort of claim to the firm's assets.

If the firm is worth nothing, no group will get anything. As the firm's assets increase in value, certain of these "ownership" groups are entitled to get paid, upon the liquidation of the corporation, ahead of other groups. At some point, the firm's assets run out, and where they run out determines how much each group will get. If the assets are sufficient to pay off every group above the holders of common stock, those shareholders, as holders of the residual rights, get what remains. For an example of a state statute laying out a scheme similar to the one just described, see Car. CoRp. Code $\$ 2004$ (West 1977).

20 If the assets are sold, these returns might be cash or marketable securities of another company. If the firm is reorganized, the returns will probably be new claims against the firm's assets. Such decisions about the deployment of assets and returns are also made, at least implicitly, each day of a firm's existence, since each day the firm's owners must decide whether to continue the business. For a healthy firm, the manner of splitting up the returns from the assets is pre-determined by contract or state law. 
owners as a group, in other words, would want to keep the distributional question from spilling over into the deployment question.

When ownership of a firm is diverse and the individual owners have different packages of rights, however, all have an incentive to take actions that will increase their own share of the assets of an ailing firm, even if in so doing they deploy the assets in a way that a sole owner would not. ${ }^{30}$ Bankruptcy law, at bottom, is designed to require these investors to act collectively rather than to take individual actions that are not in the interests of the investors as a group. Individual diverse owners have a particular incentive to act against the collective interest in cases where, under nonbankruptcy law, some owners are entitled to be paid before others ${ }^{31}$ and where the available assets are insufficient to satisfy all those with rights to them. A fully secured creditor, for example, has the right to be paid before more junior creditors receive anything. ${ }^{32}$ Like any other person assured of full payment if the business were to stop, he will tend to favor an immediate liquidation, even in circumstances in which a sole owner would keep the assets together. As a senior debtholder he has nothing to gain from waiting and attempting to keep the firm intact,,$^{33}$ but he can do worse if the firm continues and its fortunes decline ${ }^{34}$-a possibility that always ex-

30 See supra note 22; cf. Ang \& Chua, Coalitions, the Me-First Rule, and the Liquidation Decision, 11 BeLl J. EcoN. 355, 355 (1980) (noting circumstances in which diverse ownership leads to decisions that do not realize maximum value for the firm's assets); Bulow \& Shoven, The Bankruptcy Decision, 9 BeIL, J. EcoN. 437, 454 (1978) (same); Roe, Bankruptcy and Debt: A New Model for Corporate Reorganization, 83 Colum. L. REv. 527, 53845 (1983) (same).

s1 A large body of finance theory literature tries to explain why hierarchical arrangements of ownership rights come about. The seminal article is Modigliani \& Miller, The Cost of Capital, Corporation Finance and the Theory of Investment, 48 AM. Econ. REv. 261 (1958). For a review of this learning, see R. Brealey \& S. Myers, Principles of Corporate Finance 355-407 (2d ed. 1984). Some aspects of this debate have recently surfaced in the legal literature regarding secured versus unsecured credit. See sources cited infra note 52.

32 See 11 U.S.C. \$ 725 (1982). In a Chapter 11 reorganization, putting aside the complication of 11 U.S.C. $\S 1124$ (1982) and its provision for non-impairment, every creditor has the right to insist upon what he would have received in a Chapter 7 liquidation. See 11 U.S.C. $\$ 1129(\mathrm{a})(7)$ (1982); see also id. § 1129(b)(2)(A) (absolute priority rule requires that every class of secured creditors receives at least the present value of its collateral). While these statutes speak in terms of a "class of claims," each secured creditor is generally in a class by itself. See Trost, Business Reorganizations Under Chapter 11 of the New Bankruptcy Code, 34 Bus. LAw. 1309, 1327 (1979).

ss Under current bankruptcy law, the senior party could not receive more than the full amount of his claim. Congress indicated that a court could confirm a reorganization plan under 11 U.S.C. $\$ 1129$ (1982) only so long as "[n]o class [is] paid more than in full." House Report, supra note 7, at 414, reprinted in 1978 U.S. CodE Cong. \& AD. NEws 5963, 6370.

3t See Roe, supra note 30, at 542-43. Professor Roe notes that some creditors may be interested in keeping a firm viable because of the opportunities to deal repeatedly with the 
ists in an uncertain world, whether the firm is solvent or insolvent, in or out of bankruptcy. ${ }^{35}$

By contrast, junior parties, who, under current law, are typically general creditors and shareholders, often have interests that pull them in the opposite direction. Members of any group of investors that would be eliminated by a present liquidation or sale of assets have nothing to lose by seeking a solution that avoids a final distribution today. ${ }^{36} \mathrm{~A}$ group that would get nothing if the business ceases will resist an immediate liquidation, even if liquidation is best for the owners as a group. ${ }^{37}$ If there is any chance, however remote, of an upswing that will bring them value, they will want to take that chance..$^{88}$ Waiting for the upswing, however, and trying to preserve the firm's good will and expertise in the meantime, involves a gamble for the owners as a group. Like all gambles, sometimes it is worth taking and other times it is not.

No single group, then, if unconstrained, will necessarily make a decision that is in the best interests of the owners considered together. ${ }^{39}$ As a first approximation, therefore, the law governing

firm, but suggests that this countervailing tendency may not amount to much in a reorganization. Id. at 543. In addition, a creditor with an especially favorable interest rate on a loan that is not otherwise subject to prepayment may have an interest in keeping a firm viable so that the loan will remain in force. Conversely, however, a creditor with a low interest rate will seek default (and, hence, acceleration), even if it leads to a premature destruction of the firm.

ss In the absence of a default, of course, a creditor, secured or otherwise, generally does not have the right to remove assets from a firm. He may (and usually does) impose other restraints on the free rein of shareholders and managers to operate the firm. See Smith \& Warner, On Financial Contracting: An Analysis of Bond Covenants, 7 J. Frn. Econ. 117, 125-46 (1979). Moreover, upon default the fully secured creditor gains the right to remove assets and has little to gain and much to lose in not cashing out. Bankruptcy petitions are often filed only after defaults to secured creditors and the filing of the petition itself is almost always itself a default under the security agreement.

36 If the firm were propelled into a bankruptcy proceeding because of cash-flow problems, it is conceivable that the firm's assets would exceed its liabilities. In such a case, the shareholders, in addition to the general creditors, have valuable rights in the debtor's assets. Shareholders share in the debtor's assets as of right only if the general creditors have been satisfied in full. See 11 U.S.C. $\$ \S 726(a)(6), 1129(b)(2)(B)(1982)$.

${ }^{37}$ This group would also resist a sale of the assets as a going concern to a third party. Such a sale would "cash out" their upside potential, yielding them nothing. Their interests have value only so long as the firm's assets are not converted into cash.

ss See R. Brealey \& S. MYrRs, supra note 31 , at 657 . In text we analyze polar cases: classes that will be paid in full and classes that will receive nothing. A marginal class-a class that will be paid some, but not all, of its claims-may favor liquidation or continuation depending principally on its analysis of the potential for upside gain (fuller payment) relative to the potential for further loss.

s9 See supra notes 22, 30 and accompanying text. Outside of bankruptcy, this phenomenon of "misbehavior" is often constrained by contractual covenants and certain forms of monitoring. 
bankruptcy in general, and corporate reorganizations in particular, should ensure that the disposition of the firm's assets is in the interest of the owners as a group. How a firm's assets are deployed should not turn on whether one, ten, or ten thousand people have rights in them. Bankruptcy law, accordingly, should aim to keep the asset-deployment question separate from the distributional question, and to have the deployment question answered as a single owner would answer it. ${ }^{40}$

The best way to approach this goal is to ensure that the parties who decide how to deploy the assets enjoy all the benefits and incur all the costs of their decisions. ${ }^{41}$ Bankruptcy rules that en-

60 As we view it, bankruptcy law addresses, in a particular context, a much more general problem. Across a number of issues, disparate owners of assets might agree, in principle, that proceeding collectively would be in their interests if the debtor was unable to pay off all of them in full. After extending credit or contributing capital, however, investors have no effective private mechanism to ensure that all investors will act in accordance with their collective interest. This situation exemplifies the problem of the "prisoner's dilemma" or the "common pool." See A. Rapoport \& A. Chammah, Prisoner's Dilemma (1965); Friedman, The Economics of the Common Pool: Property Rights in Exhaustible Resources, 18 UCLA L. REv. 855 (1971); Sweeney, Tollison \& Willett, Market Failure, the Common Pool Problem, and Ocean Resource Exploitation, 17 J.L. \& Econ. 179 (1974). Viewed in this manner, the principal role of bankruptcy is to preserve by legal rule the collective benefits that the investors can gain for themselves as a group if they act together (and would likely bargain for before the fact if they could), and to supplant the incentives each creditor or equityholder would otherwise have to protect his own interests at the expense of the collective good. See Jackson, Non-Bankruptcy Entitlements, supra note 3, at 859-71. Bankruptcy is, in short, a mechanism to make disparate owners act as one owner would act, and thereby to reduce the costs such dispersion would otherwise bring.

One can think of bankruptcy law as simply a procedural framework, see 2 G. GrLMore, Securtyy Interests in Personal Property 1284 (1965), but it is in fact something more. Bankruptcy law provides the owners of a firm's assets with a forum in which their rights can be identified; at the same time it tries to create a mechanism that puts the assets to the use that the creditors as a group would value most. Bankruptcy law typically overrides rights that exist outside of bankruptcy only when recognition of those rights would interfere with the process that substitutes a collective proceeding for individual rights. For example, the trustee's voidable preference power, see 11 U.S.C. \$ 547 (1982), alters state-law entitlements only to ensure that creditors cannot opt out of the collective proceeding and put their selfinterest above the interest of the investors as a whole. For a discussion of the trustee's voidable preference power, see Jackson, Avoiding Powers, supra note 3; Note, Preferential Transfers and the Value of the Insolvent Firm, 87 YALE L.J. 1449, 1454 (1978).

11 For an example of a court applying this reasoning, see Reading Co. v. Brown, 391 U.S. 471, 478 (1968) (holding that tort claimants, whose claims arose out of postpetition torts, were entitled to recover ahead of "existing creditors [who] hope that by partial or complete postponement of their claims they will, through successful rehabilitation, eventually recover from the debtor either in full or in larger proportion"). In Reading Co., the Court explained the rationale of its holding by stating that:

[I]n considering whether those injured by the operation of the business during an arrangement should share equally with, or recover ahead of, those for whose benefit the business is carried on, the latter seems more natural and just. Existing creditors are, to be sure, in a dilemma not of their own making, but there is no obvious reason why they 
able classes of investors to gain from any upswing in the firm's fortunes, while avoiding the full costs of an attempt to keep the assets together, create an incentive for those investors to make such an attempt, even if it is not worth making for the investors as a group. ${ }^{42}$ That is, they will attempt to reorganize even when an individual who had complete ownership of the assets would liquidate them immediately. Imposing on junior parties the risks of keeping a firm intact removes this incentive. They become like a sole owner in the sense that they suffer the consequences of making the wrong decision and enjoy the benefits of making the right one. Unless the law imposes these burdens on them, junior parties will systematically make decisions that ignore the real costs of keeping a firm together.

\section{The Secured Creditor's State-Law Rights}

The question of whether a firm should be kept together as a unit is usually answered by estimating the income stream the assets would generate if they were kept together, discounting that stream to present value, and comparing it to the amount the assets would realize if they were sold off in separate pieces. ${ }^{43}$ According to this view, a firm should be kept intact only if it has more value as a going concern than liquidated, because only then will the assets be put to their highest-valued use. We are inclined to accept, as a general proposition, that those with rights in a debtor's assets are moved, for the most part, by the course of action that brings them the highest return under existing legal rules." however, does not depend on this assumption. We assume only that the assets of a debtor should be deployed in a way that advances the interests of those with rights in them, that these individuals would find some firms worth keeping intact and others not,

should be allowed to attempt to escape that dilemma at the risk of imposing it on others equally innocent.

Id. at 482-83. The need to ensure that those who stand to gain also bear the costs is pointed out in a different context in Easterbrook \& Fischel, Corporate Control Transactions, 91 YALE L.J. 698, 698 (1982).

12 This point is developed supra notes 21-23 and accompanying text.

4s See, e.g., J. Van Horne, Financial Management and Policy 105-41 (5th ed. 1980).

11 Like all general propositions, this one is subject to qualification. Even in pure finance theory, it is not completely clear that investors would unanimously favor a single course of action. See, e.g., DeAngelo, Competition and Unanimity, 71 AM. EcoN. REv. 18 (1981); Makowski, Competition and Unanimity Revisited, 73 Am. Econ. Rev. 329 (1983). Moreover, there may be limits on the extent to which the conduct of firms can be controlled by the signals sent by exogenous legal rules. See Engel, An Approach to Corporate Social Responsibility, 32 Stan. L. Rev. 1, 55 (1979). 
and that junior parties are reasonable surrogates for the creditors as a group when it comes to deciding how the assets should be deployed if, but only if, they bear both the benefits and burdens of their decision. Our analysis does not depend upon who the junior parties are, upon what the appropriate social policies to be pursued are, or upon whether the appropriate course is to reorganize, to sell the assets together, or to sell the assets piecemeal.

Once one accepts the idea that bankruptcy law is primarily concerned with recognizing nonbankruptcy entitlements and ensuring a deployment of assets that is in the interests of all those with rights to the assets under state law, analysis of adequate protection of secured creditors in bankruptcy is straightforward. Questions about the desirability of secured credit and the wisdom of allowing secured creditors to be paid in full ahead of others are not relevant. These questions, like questions about the rights of employees of failing enterprises, are not bankruptcy questions. If secured credit is undesirable, it is as much so outside of bankruptcy as in. Limiting it indirectly by changing bankruptcy rules is counterproductive to the basic goal of bankruptcy: using a collective forum to preserve the value of assets for the benefit of those who own them. ${ }^{48}$ Our argument, then, does not rest on an assump-

45 To be sure, one of the most prominent features of bankruptcy law is an individual's right to a discharge and a "fresh start" in life. See Perez v. Campbell, 402 U.S. 637, 648 (1971); Local Loan Co. v. Hunt, 292 U.S. 234, 244 (1934). The conditions upon which the court may grant a discharge are set out in 11 U.S.C. $\$ 727$ (1982). But this right is not relevant when the debtor is a corporation. Under state law, the owners of such an entity-the shareholders and the creditors-are liable only to the extent of their initial investments. Shareholders do not have a discharge right in bankruptcy because they already have one under state law. See Posner, The Rights of Creditors of Affiliated Corporations, $43 \mathrm{U}$. ChI. L. REv. 499, 503 (1976).

There may be a need to provide continuing corporations with a discharge, but the reasons for doing so have nothing to do with a fresh-start policy. In the case of individuals, discharge frees up the future earning power of an individual, a potentiality that is not considered an "existing" asset. See Local Loan Co. v. Hunt, 292 U.S. 234, 245 (1934); 11 U.S.C. $\S 541(\mathrm{a})(6)$ (1982) (compensation for services performed by individual debtor following commencement of case not property of the estate). For a corporation, however, there is no comparable distinction between "existing" and "future" assets either in theory or in practice. A corporation's future earning potential is measured by the productive value of its present assets. Whether liquidating piecemeal or continuing as a reorganized enterprise, a corporation's present value consists of the capitalization of the earnings stream expected to be derived from its existing assets.

It is important to provide a reorganizing corporation (or any continuing corporation that uses bankruptcy) with a discharge for another reason: to avoid affecting the correct economic decision as to the deployment of that corporation's assets. Because the assets of a corporation can be freed from liabilities by liquidation and dissolution under nonbankruptcy law, its owners will not make an unbiased decision about what to do with the corporation's assets unless those assets are similarly freed of existing liabilities following use of 
tion that secured credit, as it currently exists under state law, is wurth having. Even though the institution of secured credit in its present form may not be easy to justify, ${ }^{48}$ we need rest on nothing more than the fact that it exists. For that reason, even if the rights of secured creditors under nonbankruptcy law were radically altered, the analysis we undertake here would be largely unaffected as long as secured creditors continued to hold a senior interest in the firm's assets. Indeed, our analysis would apply to any case in which some claimants-bondholders, workers, or tort victimswere senior to others under nonbankruptcy law.

We can focus our analysis of the rights of secured creditors in bankruptcy, then, by posing two questions suggested by the view of bankruptcy law set forth in Part I. First, what are the existing nonbankruptcy rights of secured creditors, and second, is any modification of those rights necessary to ensure that the assets of the firm are deployed in a way that is in the interests of the owners of the firm as a group? ${ }^{47}$ We address the first of these questions in this Part of the article, turning to the second in Parts III and IV.

the bankruptcy process. A corporation that passes through bankruptcy and "continues," has, in effect, sold its assets, stripped of the claims of its investors, to a new entity, and distributed the proceeds of that sale to the existing investors. See Clark, The Interdisciplinary Study of Legal Evolution, 90 YALE L.J. 1238, 1250-54 (1981); Jackson, Non-Bankruptcy Entitlements, supra note 3, at 893-95. This analysis of what happens when a corporation "continues" after bankruptcy holds true whether the assets are sold as a group to a third party or the public under Chapter 7, or sold to the existing investors themselves, in which case the process is called a reorganization under Chapter 11.

Two conclusions follow. First, the social policy embodied in the rights of individuals to a "fresh start" through the bankruptcy process simply is not at issue when one is discussing rights among investors in a corporation. Second, because the assets of a corporation can be freed from the claims of its investors, including those of secured creditors, by either dissolution or use of Chapter 11, the adequate protection rule goes not to whether the assets will be put to a "fresh start" but rather to how the proceeds of the sale, be it dissolution or reorganization, are to be allocated. The question is not, in the first instance, whether the corporation should reorganize, but, rather, who should pay for it.

so See infra note 52 .

47 If it turns out that one cannot both protect the rights of the secured creditor and induce the use of the assets the owners as a group would favor, one would have to devise some means of accommodating the two bankruptcy policies and minimizing the costs associated with departing from either. See Rosenberg, Beyond Yale Express: Corporate Reorganization and the Secured Creditor's Rights of Reclamation, 123 U. PA. L. REv. 509, 536-46 (1975) (arguing for balancing by use of tax subsidy). One would have to evaluate first the disadvantages that come whenever rights are limited in bankruptcy but not elsewhere, and then weigh these disadvantages against the loss that all the creditors and other investors suffer from an undesirable deployment of their assets. On the other hand, if the two policies are not inconsistent, then as long as the nonbankruptcy entitlement exists one should protect the secured creditor in full, or, at least, come up with a bankruptcy reason for not doing so. 


\section{A. The Nature of Security: A Form of Ownership Priority}

Many analyses of secured credit assume that its characteristic feature is the ability of the secured creditor to seize property of the debtor should the debtor default on a primary obligation. ${ }^{48}$ This right, however, is relatively unimportant in distinguishing between secured and unsecured creditors. Virtually all extensions of credit give a creditor a contingent right to take possession of a debtor's property if the debtor should fail to pay his debts when due. A host of state collection laws is concerned with how a creditor, secured or unsecured, goes about the process of reducing his claim to judgment and then "executing" or "levying" on the debtor's property in order to satisfy that judgment. ${ }^{40}$ While the secured creditor has the right, not enjoyed by the unsecured creditor, to take property without the post-default consent of the debtor and without going to court, ${ }^{50}$ this right is insubstantial in practice, for a debtor's active objection will require the secured creditor to go to court as well. ${ }^{\mathrm{s1}}$

The essence of a secured creditor's rights, therefore, is not captured by focusing on the debtor-creditor relationship. Rather, secured credit is concerned with ensuring that the secured creditor receives priority rights in certain assets over the rights of other owners with claims against the assets of a debtor. The property right, in other words, is principally a means to an end-priority as against third parties with regard to repayment. As one would expect, however, secured creditors must pay a price for the package of rights that assures their priority and, hence, their lower degree of risk. Because a secured creditor bears less risk of his debtor's insolvency than does an unsecured creditor, he enjoys a lower interest rate than the unsecured creditor. In this respect, however, the secured creditor's right is no different from that of an unsecured creditor to get paid ahead of the shareholders, and it is a mistake to treat it as somehow different in kind. ${ }^{\mathbf{b 2}}$ Secured credi-

48 See, e.g., V. Countryman, A. Kaupman \& Z. Wiseman, Commercial Law: Cases and Materials 3-5 (2d ed. 1982); see also U.C.C. § 9-503 (1978) (defining the scope of the secured creditor's right to take possession of the collateral).

40 See, e.g., N.Y. Civ. Prac. Law \$§ 5201-5235 (McKinney's 1978).

so See U.C.C. \& 9-503 (1978).

s1 Id.; see, e.g., Deavers v. Standridge, 144 Ga. App. 673, 673-74, 242 S.E.2d 331, 332-33 (1978); Stone Machinery Co. v. Kessler, 1 Wash. App. 750, 750-53, 463 P.2d 651, 651-52 (1970). A secured creditor, unlike an unsecured creditor, may also be entitled to resort to exempt property. See, e.g., State v. Avco Fin. Serv., 50 N.Y.2d 383, 387-88, 406 N.E.2d 1075, 1077, 429 N.Y.S.2d 181, 183-84 (1980).

${ }^{B 2}$ Secured credit is to unsecured credit what unsecured credit is to equity interests; 
tors, unsecured creditors, and shareholders all ultimately have some rights against the assets. ${ }^{53}$ That the rights are hierarchically arranged merely reflects the different bargain each interest holder has struck in acquiring those rights. ${ }^{54}$

This observation about the nature of a secured creditor's property rights suggests something fundamental about secured credit. A secured creditor's property right is limited in its scope by its purpose, which is to implement the secured creditor's priority right. In acquiring a security interest, a secured creditor does not "buy" a right to the asset itself, but, rather, he buys a right to use the asset to gain repayment of the debtor's debt to him. The limited nature of the secured creditor's interest in property is reflected in the governing law, Article 9 of the Uniform Commercial Code, which does not allow the secured creditor to keep the collateral without the consent of the debtor. The secured creditor's ultimate remedy is to sell the asset and thereby realize the asset's value in the marketplace. ${ }^{.5}$ In practice, then, a secured creditor

each represents a different level of investment with different risks and different associated returns. Secured creditors do not suddenly appear on the scene. They are investors, like unsecured creditors and shareholders. They bargain and pay for their special rights. Moreover, they must provide other investors with notice of their rights. One generally cannot assert a security interest against anyone with the rights of a judgment creditor unless one has taken possession of the collateral or has given public notice of one's interest. See U.C.C. $\S \S 9-301,9-302,9-305$ (1978). Notice must be given in order to prevail against general creditors in bankruptcy. The trustee in bankruptcy acts in the first instance on behalf of the general creditors, and under the Bankruptcy Code, the rights of the trustee, in the case of personal property, are determined by the rights of a judgment creditor. See 11 U.S.C. $\S$ 544(a) (1982).

There does not seem to be anything inherently unfair about giving secured creditors (as well as unsecured creditors and shareholders) in a bankruptcy proceeding exactly what they bargained for before the fall. Eisenberg, supra note 3 , at 965 . It is entirely possible, and indeed very likely, that those who insist on secured credit, and those, including shareholders, who do not, do so for a reason, and that this reason advances the interests of all investors, creditors and shareholders alike. This analysis of secured credit is pursued further in D. Baird \& T. Jackson, Cases, Problems, and Materials on Security Interests in PerSONAl Property 361-67 (1984); Jackson \& Kronman, Secured Financing and Priorities Among Creditors, 88 Yale L.J. 1143 (1979); Levmore, Monitors and Freeriders in Commercial and Corporate Settings, 92 YaLE L.J. 49 (1982). But cf. Schwartz, Security Interests and Bankruptcy Priorities: A Review of Current Theories, 10 J. Legal Stud. 1, 3 (1981) (no efficiency theory of secured credit by itself adequately explains the shape of current secured credit).

"Ts These rights can be thought of as "options" on the firm's assets. See Black \& Scholes, The Pricing of Options and Corporate Liabilities, 81 J. PoL. Econ. 637, 649 (1973).

B4 Nonconsensual creditors, such as tort victims, may not make such adjustments. Questions over the priority of tort claimants, given the goals of a tort system, are a nonbankruptcy issue. See Note, Tort Claimants in the Secured Credit System, 36 Stan. L. Rev. (1984) (forthcoming).

ss See U.C.C. $\S \S 9-504,9-505$ (1978). Similarly, real estate law requires a foreclosure 
only has the right to the cash he could raise upon the sale of the property, not to any value deriving from its continued use. This definition of the secured creditor's remedy suggests that the probability of repayment and not any intrinsic interest in the collateral itself is the principal element of the value of his bargain with the debtor.

\section{B. Valuing the Secured Creditor's Rights}

Consider the following example. Investor lends Firm $\$ 10,000$. Firm promises to repay Investor in one year. If it were certain that Firm would repay that $\$ 10,000$ on time there of course would be no reason to have security. Security is valuable precisely because it is not certain Firm will repay the $\$ 10,000$ in full and on time. Even if Firm were certain to repay the $\$ 10,000$ at the end of the one year, Investor would insist on some form of interest. Receiving $\$ 10,000$ one year from now is not the same as having $\$ 10,000$ in hand today, even in a world in which inflation is absent and repayment is certain. $^{\mathrm{s}}$

Firm, of course, is not certain to repay the $\$ 10,000$ in full and on time. There is a risk that Firm will either hide its assets ${ }^{57}$ or be insolvent. Above and beyond the inherent time value of money, the risk of nonrepayment increases the cost of lending $\$ 10,000$ to Firm, and Investor, if his transaction is voluntary, will insist on receiving compensation for taking that risk. If Investor takes a security interest in Firm's drill press, and if that drill press is worth $\$ 10,000$, Investor may, of course, be able to reduce the risk substantially by shifting some of it to Firm's other investors, ${ }^{58}$ but he will not be able to eliminate it entirely. There is, first of all, a risk that the drill press will decline in value either because of fluctuations in its market value or because it wears out as it is used and, thus, depreciates in value. There is also a risk that Firm will not allow Investor to have the drill press upon default, forcing Investor to resort

sale, often under court supervision.

so See R. Brealey \& S. Myers, supra note 31, at 10-22.

s7 Such action would doubtless constitute a fraudulent conveyance. See UNIF. FrauduLENT Conveyance ACT \$ 4, 7A U.L.A. 205 (1978); cf. Clark, The Duties of the Corporate Debtor to Its Creditors, 90 HARv. L. REv. 505, 517-33 (1977). But a fraudulent conveyance action against a debtor will provide little solace when, as is usually the case, the debtor is insolvent and the assets either cannot be traced or are in the hands of a bona fide purchaser for value. See Unif. Fraudulent Conveyance Act § 9(1), 7A U.L.A. 304 (1978).

${ }^{88}$ Consensual unsecured creditors will charge more for bearing this increased risk as long as they know the rules of the game when they extend credit. Jackson \& Kronman, supra note 52, at 1147-50. 
to a lengthy court proceeding to obtain the asset. Such a delay imposes costs of two sorts on Investor. First, Investor continues to bear the risk of depreciation and value fluctuation. Second, even if the collateral does not depreciate and is stable in value, Investor bears the time value cost of delay. It is not enough to say that Investor has a right to the collateral in priority to other creditors: One has to establish when Investor has a right to the collateral. ${ }^{59} \mathrm{~A}$ secured creditor with a right to take possession of a $\$ 10,000 \mathrm{ma}-$ chine in January and sell it is better off than a secured creditor with a right to take possession of a $\$ 10,000$ machine in July.

To insist upon a difference between depreciation and time value is to misunderstand the nature of private property. Ownership of an asset is nothing more than a right to make some use of that asset over time. If one postpones or takes away the right to a piece of property for some period, one compromises the rights of the owner even if the asset lasts forever. For this reason, the government must pay compensation even if it takes undeveloped real property only for a few years and then returns it to the original owner. For the same reason, one cannot ask simply how much the secured creditor would receive under state law. One must also ask when he would receive it.

When Investor calculates the rate at which he will be willing to lend Firm money on a secured basis, he must take into account when he will be able to foreclose on and sell the collateral just as surely as he must take into account the likelihood of its physical depreciation. Under state law, the filing of the bankruptcy petition usually identifies the "when." Under virtually all security agreements, Investor's right to seize his collateral and sell it to satisfy the debt ripens no later than the filing of the bankruptcy petition. ${ }^{60}$ Foreclosure and sale may take time, particularly if Firm is recalcitrant, ${ }^{61}$ but the state-law process could be set in motion by the time of filing. If Investor is not given the liquidation value of the asset at the time he would have enjoyed it if a default occurred

so For further discussion of the secured creditor's interest in the timing of his right to the collateral, see D. BAIRD \& T. JACKSON, supra note 52, at 523-25; Jackson, Non-Bankruptcy Entitlements, supra note 3, at 872-77; James \& Kirkland, Adequate Protection Through Augmented Interests in Reorganization Plans, 58 AM. BANkr. L.J. 69, 72 (1984).

so See U.C.C. \$\$ 9-503 to -505 (1978). Indeed, bankruptcy supplies default and acceleration as implied terms. See House RBPORT, supra note 8, at 353, reprinted in 1978 U.S. Code Cong. \& AD. News 5963, 6309 (stating that 11 U.S.C. $\$$ 502(b) (1982) incorporates the principle of existing law that "bankruptcy operates as the acceleration of the principal amount of all claims against the debtor").

-I If Investor cannot repossess the collateral "without breach of the peace," he must seek the assistance of a court. U.C.C. § 9-503 (1978). 
and a bankruptcy petition had not been filed, his state-law rights are not being protected.

The intrinsic value of Investor's security interest, therefore, is the right it gives him to sell the drill press and thereby to obtain its liquidation value ahead of the rights of other creditors at a particular time. This liquidation value represents the value a purchaser would expect to derive from use of the drill press over time. In determining what to pay for the drill press, such a purchaser would look to both the value of using it in his own business and the value inherent in the benefits he might gain from selling it back to Firm ${ }^{62}$ or to yet another party, who, in turn, would make the same calculation. In short, the liquidation value is derived from the going-concern value of the asset in the hands of a thirdparty purchaser..$^{63}$

\section{Bankruptcy and the Secured Creditor}

Under existing nonbankruptcy rules, a sole owner of assets may freely decide whether to continue an unsuccessful business

-2 To understand this element of the collateral's value in the hands of a third party, consider the following. Firm owns a printing press that is worth $\$ 50,000$ in the hands of a third party. However, because it is tailored to Firm's operations and cannot be quickly replaced by buying another press on the market, the press is worth $\$ 60,000$ in Firm's hands. Firm has granted a security interest in this printing press to Investor to secure a $\$ 75,000$ loan.

Upon a default by Firm, what is the "value" of this security interest to Investor? Without bankruptcy, Investor could repossess the machine and sell it (after some delay) for $\$ 50,000$. At a minimum, the value of this security interest is that it allows Investor to recover $\$ 50,000$, subject to whatever costs he faces from the time it takes to exercise his rights under state law. It may be appropriate for bankruptcy law to recognize this delay in some fashion-perhaps by postponing until sometime following the filing of the petition the point at which the secured creditor must be adequately protected. $C f$. General Electric Mortgage Corp. v. South Village, Inc. (In re South Village, Inc.), 25 Bankr. 987, 996 n.14 (Bankr. D. Utah 1982) ("The date of the petition, however, may be irrelevant to opportunity cost which would accrue only from the date upon which the creditor-absent the stay-could first liquidate the collateral ....").

If the printing press is worth $\$ 60,000$ in the hands of Firm, however, it is not so clear that its market value will be only $\$ 50,000$. Absent information- or transaction-cost barriers, any third party purchasing the press knows that he should be able to sell it to Firm for more than $\$ 50,000$. See Klein, Crawford \& Alchian, Vertical Integration, Appropriable Rents, and the Competitive Contracting Process, 21 J.L. \& Econ. 297, 298-99 (1978); Leff, Injury, Ignorance and Spite-The Dynamics of Coercive Collection, 80 YALE L.J. 1, 5-26 (1970). Hence, even though Investor is entitled only to the liquidation value of the asset, this value-the amount the machine will fetch on the market-may reflect some of the value of the machine in Firm's hands. In short, the difference between liquidation value and goingconcern value may not be as great as is often assumed.

ss Note that the "going-concern value" of the assets in the hands of Firm is calculated the same way: by comparing the capitalized expected returns of Firm's business without the asset with the capitalized expected returns of Firm's business with the asset. 
venture or to do something else with the assets, depending upon what he thinks is in his interest. A bankruptcy proceeding helps to ensure a comparable freedom where ownership of the ailing firm is diverse. In the absence of a coercive and collective proceeding, the dispersed owners' individual interests will prevent them from acting as a single owner would. In this Part of the article, we ask whether recognizing the rights of a secured creditor to repossess collateral interferes with that goal.

In a world without friction, it would not. If the secured party's collateral is, in fact, worth more to the firm than to a third party, that collateral should end up back in the hands of the firm notwithstanding its repossession by the secured creditor in the interim. ${ }^{64}$ As a practical matter, however, to permit a secured creditor the full exercise of his rights may hinder efforts to preserve the going-concern value of the business. ${ }^{65}$ It may be in the interests of the owners as a group to stay the repossession rights of the secured creditor and to substitute a requirement that the secured creditor instead accept the asset's liquidation value. Because of the costs repossession and subsequent repurchase may bring, it is consistent with the purposes of bankruptcy to substitute for a secured creditor's actual substantive rights under nonbankruptcy law a requirement that the secured creditor accept the equivalent value of those rights. ${ }^{68}$

4h See Jackson, Non-Bankruptcy Entitlements, supra note 3, at 870-71; cf. Coase, The Problem of Social Cost, 3 J.L. \& EcoN. 1, 2-15 (1960) (in world free of transaction costs, original entitlement questions not relevant to the question of how assets are deployed because they will end up in the hands of highest-value user).

${ }^{65}$ Because of lower transaction costs, for example, it may prove less expensive to refinance the asset, paying the original secured creditor its liquidation value while leaving the asset itself in the hands of the firm.

os See United States v. Whiting Pools, Inc., 103 S. Ct. 2309, 2314-15 (1983). This helps to distinguish two sorts of comments made concurrently in the House and Senate Reports on the Bankruptcy Code. The court in In re American Mariner Indus., 27 Bankr. 1004, 1009 (9th Cir. Bankr. App.), appeal docketed, No. 83-5806 (9th Cir. 1983), relied on the comment in those reports that "[t]here may be situations in bankruptcy where giving a secured creditor an absolute right to his bargain may be impossible or seriously detrimental to the policy of bankruptcy laws," SENATE REPORT, supra note 7, at 53, reprinted in 1978 U.S. CODE Cong. \& AD. News 5787, 5839; House REPoRT, supra note 7, at 339, reprinted in 1978 U.S. Code Cong. \& AD. NEws 5963, 6295, as a justification for not awarding opportunity cost. But the court did not quote the remainder of the paragraph. One sentence later, the reports make clear that this comment refers only to limiting rights, not to denying the secured creditor the value of those rights: "Though the creditor might not receive his bargain in kind, the purpose of the section is to insure that the secured creditor receives in value essentially what he bargained for." SENATE REPORT, supra note 7, at 53, reprinted in 1978 U.S. Code Cong. \& AD. News 5787, 5839; House Report, supra note 7, at 339, reprinted in 1978 U.S. Code Cong. \& AD. News 5963, 6295. This distinction is the proper one. Recognizing rights per se may interfere with the goals of a bankruptcy process; recognizing value, as we 
We then must ask if there is anything in the goals of the bankruptcy process that suggests that respecting the value of a secured creditor's rights in full also interferes with the goals of bankruptcy. The relevant bankruptcy goal, as we have seen, is not that a firm stay in business, but rather that its assets are deployed in a way that, consistent with applicable nonbankruptcy restrictions, advances the interests of those who have rights in them. When there is no "going-concern surplus," a reorganization would seem inappropriate because the firm's assets are worth more (and hence the owners recover more of what they advanced the debtor) if the assets are sold and used by third-party purchasers than they are if kept together. ${ }^{68}$ Conversely, when a firm's assets are worth more as

will show, cannot.

${ }^{67}$ Whether the assets have a going-concern surplus is determined by looking at the return they yield to parties having rights in the assets. Applicable nonbankruptcy rules may affect the existence and extent of any going-concern surplus. For example, a "going out of business" tax may lead an owner of assets to keep them running as a business when, absent the tax he would not. The value of assets in various uses, in other words, can be affected by nonbankruptcy policy decisions. Such nonbankruptcy policy decisions should be implemented, however, across the board and not only in bankruptcy.

${ }^{88}$ One should ask whether the same analysis would apply if a sole owner would want to keep the firm intact even though its assets would be worth more if liquidated. Assume Firm has assets that can be sold for $\$ 50,000$. Firm itself, however, is worth only $\$ 40,000$. Such a case might arise if Firm were to use its assets to make a product (such as violing) that was not in demand, instead of another product (such as electric guitars) that was. Assume that a sole owner would keep the assets in their present use nevertheless, perhaps because he thought the world would be a better place if the craft Firm practices (violinmaking) were preserved, and it was worth $\$ 10,000$ to him to help it happen. Finance Company has lent $\$ 50,000$ to Firm and has taken a security interest in Firm's assets. Bank, an unsecured creditor, has lent $\$ 10,000$ to Firm. In our analysis, Bank will ultimately bear the burden of keeping Firm in business. If Bank bears this burden, will it have less incentive to be altruistic than a sole owner would? In principle, we think it will not. The benefits Bank would perceive from being altruistic should be independent of the resources it has (or has not) already devoted to the enterprise.

The group (Bank and Finance Company together) might be more willing to keep Firm together than Bank alone would be. (Like a sole owner, each might be willing to spend $\$ 10,000$ to preserve the craft of violinmaking.) But there is no reason to believe that Bank alone or any other member of the group would be less altruistic than a sole owner. We see no reason as a general matter to design legal rules to ensure disparate owners are more altruistic than sole owners. See Engel, supra note 44. Moreover, we do not think that those who decide whether a firm should stay together for altruistic reasons should be able to force others to shoulder the costs such a decision entails. We also note that in the case of a healthy firm with disparate owners, the most junior owners, the shareholders, are also the ones who bear all the costs of being altruistic.

Addressing a related issue in a recent article, Professor Nimmer suggests that the argument behind compensating time value through adequate protection not only fails to account for the cost it imposes in "effectively preclud[ing] reorganization in many cases," but also rests on "an assumption of economically rational actors acting to optimize benefits." Nimmer, Secured Creditors and the Automatic Stay: Variable Bargain Models of Fairness, 68 Minn. L. REv. 1, 13-14 (1983). He proposes a model of adequate protection that is derived 
a going concern, the owners, as a group, are probably better off if the assets are kept together, even though the firm may have defaulted on some of its obligations or may be insolvent. ${ }^{69}$

The crucial question we have to face is whether giving the secured creditor the benefit of his bargain is inconsistent with the policy of ensuring that the firm's assets are deployed in a way that brings the most benefits to the owners as a group. The rights of a creditor who has a security interest in a drill press are fixed by seeing how much the drill press would bring if it were sold to some third party on the open market. ${ }^{70}$ If the firm is in fact worth more as a going concern than sold piecemeal, then there must necessarily be enough to pay a secured creditor the full liquidation value of the machine. One follows from the other. To say that a firm has a going-concern surplus is simply to say that the sum of the liquidation values of its assets if sold one by one is less than the goingconcern value of those assets kept together. ${ }^{71}$

from the type of result that should follow from different behavioral assumptions and a focus on "overall reorganization goals." Id. at 51.

We disagree with Professor Nimmer's impressive effort largely because we do not think that recognizing the state-law rights of secured creditors has the effect, in principle, of discouraging reorganizations the owners as a group would desire. To the contrary, we believe that a failure to recognize the rights of senior claimants systematically skews the decision of residual claimants so that they will tend to favor reorganization even when the claimant group as a whole would favor liquidation.

In making this argument, we do not assume that the actors in a bankruptcy proceeding are rational profit-maximizers. Rather, we make the more modest assumption that those involved in a bankruptcy proceeding are sensitive in some measure to the economic costs and benefits of their actions, and that legal rules should ensure that the decisions of those involved are not, as a result of this sensitivity, systematically biased in favor of either liquidation or reorganization. Making certain that the residual claimants enjoy the same benefits and incur the same costs as a sole owner does not depend on deep assumptions about economic rationality. Whatever the basis for a decision, it should not be distorted because the benefits fall on one party and the costs on another. Whether residual claimants act in a way that is aconomically rational when their incentives are not skewed is entirely up to them. It is only common sense that they bear the costs of their decision. Those who call the tune should pay the piper.

"A Airm's liabilities could, for example, exceed its assets because of torts the firm committed in the past when it was engaged in selling a different kind of product. Whenever a firm is insolvent, defaults are inevitable, even if the firm has value as a going concern.

70 Some secured creditors have argued that their rights should by judged by the collateral's "going-concern" value, and not by its liquidation value. A going-concern valuation would overcompensate them, however, because such a valuation is not a right that they have under state law. See supra note 62 . On the other hand, the differences between the two valuations are probably not as great as bankruptcy judges often make them seem, at least when a secondary market for the collateral is well developed. A liquidation value is not the same as the price the collateral would fetch in a fire sale. Liquidation value also should include the value that a third party would enjoy by virtue of having the opportunity to sell it back to the debtor. See supra note 62.

${ }^{21}$ Both going-concern and liquidation values represent future income streams dis- 
Let us assume that a drill press is a firm's sole tangible asset and that a third party would pay $\$ 10,000$ for it as of the time of the bankruptcy petition. If the firm is worth preserving as a going concern (on account of the good will it has generated among its customers and its expertise in running the machine), it must be the case that the firm is worth more than $\$ 10,000$ as of that time. If it is not worth more, the drill press is not being used effectively, and the firm is not worth preserving as a going concern.

A firm that is worth more than $\$ 10,000$ as of the time of the bankruptcy petition is capable of giving a secured creditor with a security interest in the drill press at least that much. It can pay him out of cash reserves, or it can borrow the money on a secured, unsecured, or equity basis from a new investor. In principle, moreover, the secured creditor does not need to be given cash at the time of the petition in order to be given the full value of his statelaw rights. ${ }^{72}$ For example, the secured creditor could be given the value of his rights if he were given rights to all the assets of the firm, subject to an option of the general creditors to repurchase the firm from him at some later time for a fixed amount. ${ }^{73}$ As long as the package of rights the secured creditor is given is worth $\$ 10,000$ - by which we mean that it can be sold by the secured creditor for that amount-he has received the value of his rights under state law.

In principle, any firm that is worth more as a going concern

counted to present value, and the concept of a going-concern surplus means that the stream represented by the going-concern value is larger than the stream represented by the liquidation value.

${ }^{72}$ See Jackson, Non-Bankruptcy Entitlements, supra note 3, at 872-74.

${ }^{73}$ See James \& Kirkland, supra note 59 , at $83-84$. That amount will be more than $\$ 10,000$ to account both for the time value of $\$ 10,000$ between the time of the petition and some fixed time thereafter, and for the risk that the assets will turn out to be worth less than $\$ 10,000$. The fallacy sometimes advanced that a secured creditor should have no cause to complain if he ultimately receives payment in full (in nominal dollars), ignores the fact that a present-value payment includes both an upside and a downside. This valuation fallacy was reflected in the proposal of the Commission on the Bankruptcy Laws of the United States to allow excluded classes to participate in a reorganization if, at the time of a "second look," the enterprise had done better than "expected." See REPORT OF THE CoMmission on the Bankruptcy Laws of . The United States (pt. 2), H.R. Doc. No. 137, 93d Cong., 1st Sess. 241 (1973) (setting forth $\$ 7-303(3)$ of the proposed Bankruptcy Act of 1973); see also Rochelle \& Balzersen, Recommendations for Amendments to Chapter X, 46 AM. BankR. L.J. 93, 99-102 (1972) (proposing a similar "second look" rule). Such proposals are sharply and cogently criticized in Spitzer v. Stichman (In re Hudson \& M.R.R.), 278 F.2d 402, 410 (2d Cir. 1960); Brudney, The Bankruptcy Commission's Proposed "Modifications" of the Absolute Priority Rule, 48 AM. BANKr. L.J. 305, 331-35 (1974); Note, The Proposed Bankruptcy Act: Changes in the Absolute Priority Rule for Corporate Reorganizations, 87 Harv. L. REv. 1786, 1811-16 (1974). 
than chopped up will be able, then, to give the secured creditor the value of his state-law rights. To be sure, giving the secured creditor the benefit of his bargain does mean that other investors, such as general creditors or shareholders, receive less or perhaps nothing of what is owed to them, but how rights to the assets are divided among the investors is, we have seen, a question distinct from that of how the assets are deployed..$^{74} \mathrm{It}$ is the difference between the size of the slices and the size of the pie. Only the latter is a bankruptcy question. Giving the secured creditor the benefit of his bargain should not prevent a firm from staying together when a sole owner would keep it together. Indeed, a failure to recognize the secured creditor's rights in full will undercut the bankruptcy goal of ensuring that the assets are used to advance the interests of everyone. If those who stand to benefit from delay do not bear its cost (including the costs that secured creditors face), they will have an incentive to keep firms together even when a sole owner would not.

\section{The Secured Creditor and the Costs of Uncertainty in Corporate ReORganizations}

Reorganizations take time. In the world as we actually find it, valuations are hard to come by. It may not be clear whether a firm is worth keeping intact. One may need time to decide whether liquidation piece by piece is the only course that is available. Whether the firm's assets have value if kept together may turn on whether there is an as-yet undiscovered third party that needs such assets in their present form (perhaps for no other reason than the tax loss they bring with them ${ }^{75}$ ). It may depend upon whether the market for the firm's goods or services changes or whether the economy as a whole turns around. Determining the optimal capital structure of a reorganized firm, moreover, takes time. But it does not follow that protecting the value of the secured creditor's statelaw rights promotes liquidations when the appropriate course is patience. Again, the appropriate focus is one that takes benefits and costs into account.

Waiting for changed conditions or for more information imposes a cost. If a firm's assets would fetch $\$ 10,000$ on liquidation today, an investor who owned the firm's assets outright would have to weigh the value of obtaining $\$ 10,000$ immediately against the

"See supra notes 24-42 and accompanying text.

7s See Roe, supra note 30, at 573 n.155. 
more uncertain value that waiting would bring. A sole owner would not necessarily delay liquidating simply because it was clear that a year later the assets would be worth, in nominal dollars, $\$ 11,000$. Assuming his goal was to enjoy the highest return on his investment, he would not keep the firm's assets together if one-year treasury bills offered a risk-free return of more than $10 \%$, since he would be certain to receive more than $\$ 11,000$ in one year's time by investing his $\$ 10,000$ today in treasury bills instead of in the firm. The analysis should be exactly the same if the firm's ownership were dispersed: Under such assumptions, it would not be in the interest of the investors as a group, seeking to enjoy the highest return on their collective investment, to attempt to reorganize. If, however, the junior parties could force a creditor holding a security interest in the firm's assets to accept $\$ 10,000$ a year hence in satisfaction of a claim worth $\$ 10,000$ today only if the firm reorganized, but not if it liquidated, they would have an incentive to keep the firm together in order to reap for themselves the benefit of $\$ 1000$, even though the creditors as a group would receive less than if the firm were liquidated immediately and they were free to reinvest the proceeds in treasury bills. If the secured creditor receives the time value of his claim, and junior creditors remain the ones who decide whether to try to reorganize, this perverse incentive is removed.

The return on an investment in a firm is usually far more uncertain than the return on treasury bills. Assume that a firm's assets may be worth $\$ 11,000$ in a year's time, but only if things go well. As best one can tell today, there is only a fifty-fifty chance that the firm can stay in business beyond a year, and if it fails after a year, a liquidation would then realize, again in nominal dollars, only $\$ 10,000$. In these circumstances, even if the risk-free rate of return were only $6 \%$, instead of $10 \%$, our sole owner would decide to liquidate the firm rather than to keep it running. Provided the owner is risk-neutral, ${ }^{76}$ liquidating the firm today and investing its proceeds in treasury bills would generate $\$ 10,600$ in a year's time, while waiting and attempting a reorganization would be expected to realize only $\$ 10,500$. To determine the value of the firm if an effort is made to reorganize, one must take into account both the value in the event of success $(\$ 11,000)$ and the value in the

${ }^{76}$ See Schwartz, supra note 52, at 23-24 (arguing that the goal of managers to maximize the market value of a corporation's stock implies that they are risk-neutral). Note that an assumption of risk aversion would only strengthen the example. See infra note 77. 
equally probable event of failure $(\$ 10,000){ }^{77}$ Again, the analysis of the choice between liquidation and reorganization should be no different if the firm has diverse owners. Unless the risk-free rate is $5 \%$ or less, the firm should liquidate. When ownership is diverse, however, this decision will be reached only if the residual class (assuming it can control the decision) bears the costs as well as enjoys the benefits of a decision to continue.

Let us take a different example. To keep it simple, we shall discount all values to current dollars. The firm again consists of assets that can be sold piecemeal for $\$ 10,000$ today. Assume, however, that this firm has an $80 \%$ chance of being worth (discounted to current dollars) $\$ 12,000$ in one year's time if an effort is made to keep the business running. There is, however, a $20 \%$ chance that the effort will fail and the assets will have to be sold on the open market at the end of the year. Such a sale will realize only $\$ 8000$ in current dollars. (The $\$ 2000$ difference between liquidation today and liquidation in a year's time arises from the time value of money and perhaps also from the depreciation that the assets will suffer in the intervening year.) In this case, the attempt to keep the business running ought to be made. If the assets are kept together for another year, the best guess of their worth in present dollars is $\$ 11,200,{ }^{78}$ while they are only worth $\$ 10,000$ if sold today piece by piece. A third party would pay $\$ 11,200$ today for the assets as a unit, while various third parties would pay only $\$ 10,000$ for the assets on a piecemeal basis. A sole owner, therefore, would keep the assets together, either in his own hands or sold to a third party.

Giving the secured creditor the value of his state-law rights in the face of uncertainty does not impair the effort to keep the assets together. If the assets are kept together and sold for $\$ 11,200$ to a third party, the secured creditor can receive his $\$ 10,000$ from the proceeds. If the firm is reorganized (in effect a sale to the existing investors who pay for the assets by relinquishing their claims against the assets), nothing changes except the nature of the compensation. The secured creditor can be given a share in the reorga-

72 To put the point schematically, .5( $\$ 10,000)+.5(\$ 11,000)=\$ 10,500$. The assumption of risk neutrality is reflected in the fact that the probability multipliers are unadjusted. A risk-averse owner would adjust the downside multiplier upwards and the upside multiplier downwards. He overvalues the risk of receiving only $\$ 10,000$ and undervalues the benefit of receiving $\$ 11,000$ relative to someone who is risk-neutral. The opposite would be the case if the owner were a risk preferrer. Throughout the present discussion, we assume risk neutrality.

78 This is the case because $.8(\$ 12,000)+.2(\$ 8000)=\$ 11,200$. 
nized company-approximately $89.3 \%$ of it $^{78}$ - worth $\$ 10,000$ today, and the next class of investors, be they general creditors or shareholders, can divide among themselves a $10.7 \%$ share in the reorganized company worth $\$ 1200$.

If an effort is made to reorganize, there is, of course, a $20 \%$ chance that the reorganized firm will fail and be sold piecemeal for $\$ 8000$ (in present dollars) in a year's time, in which event a secured creditor who did not resell his shares would eventually receive less than full payment (approximately $\$ 7140$ ) ${ }^{80}$ and the other investors would receive something (approximately $\$ 860$ ) for their new 10.7\% share. But if the secured creditor is compensated for the risk of failure, he is not being injured. In other words, he is fully compensated if he is given enough stock so that, in the event of success, his share in the reorganized company will be worth, in today's dollars, approximately $\$ 10,715 .^{81}$ The extra $\$ 715$ of present value in the event of success compensates the secured creditor for the one chance in five that he will suffer a $\$ 2860$ loss in the event of failure. ${ }^{82}$

Unlike a sole owner, dispersed investors, because their relative rights differ, have an incentive to make the wrong decision if unchecked. ${ }^{83}$ The secured creditors will rush to liquidate, while the general creditors and shareholders (who often have more to gain than to lose from delay) will be too optimistic and push for a reorganization. ${ }^{84}$ Bankruptcy law makes a grave mistake if it assumes that a junior class (or another class) will make the correct decision

79 The expected value of the company today is $\$ 11,200$. If the secured creditor is given a little less than $89.3 \%$ of the stock in the company, assuming no other form of ownership claim is used, his stock will have a present value of $\$ 10,000$.

${ }^{80}$ Again, to lay things out explicitly, $.893(\$ 8000)$ equals approximately $\$ 7140$.

81 If the firm succeeds and in one year's time is worth $\$ 12,000$, discounted to present dollars, then the secured creditor's share of slightly less than $89.3 \%$ will be worth $\$ 10,715$ in today's dollars.

s2 See Brudney, supra note 73, at 333 .

ss As this article has emphasized, rarely will a single person have complete ownership of a firm. There will typically be, inter alia, bondholders, debentureholders, trade creditors, shareholders, and managers, none of whom have interests that correspond exactly with the interests of everyone collectively. Shareholders capture most of the upside gains from risky ventures and do not suffer all the downside risks. Lenders (both secured and general) will tend to want the firm to take too few risks (or too few risks of the sort that are not accounted for before the fact in their initial bargain). The managers of the firm neither enjoy all the gains from their decisions nor experience all the losses. Much of corporate and contract law, and not simply bankruptcy law, must address this problem. See Easterbrook \& Fischel, supra note 41, at 700-03; Jensen \& Meckling, supra note 22, at 353-54; Levmore, supra note 52, at 59-65; see also Brudney \& Clark, A New Look at Corporate Opportunities, 94 HaRv. L. Rev. 997, 1022-42 (1981).

st See supra notes 24-38 and accompanying text. 
about the deployment of the assets without a legal rule that forces it to take account of the investors as a group. In the world as we find it, chances of success or failure over time can never be calculated with certainty. But to say that they cannot be calculated with certainty is not to say that they cannot be calculated at all. Everyone in his day-to-day life weighs the benefits of certain sums in the present against the benefits of uncertain sums in the future. Wrong decisions are surely made, but the best way of ensuring the correct decision-by which we mean the decision that is not distorted by the self-interest of individuals at the expense of the interests of the group-is to create a legal rule that imposes upon the person who makes the decision all the benefits if he decides correctly and all the costs if he guesses wrong. A rule that forces general creditors and shareholders to give secured creditors the full value of their claims (including compensation for the time value of money) puts the cost of a decision to reorganize the firm entirely on the junior classes, who already stand to benefit if the firm succeeds. As a consequence, they have incentives that approximate those of a sole owner, and their decision about how to deploy the firm's assets will not be distorted by self-interest.

\section{Bankruptcy Policy and the Bankruptcy Code}

To this point, our argument has been both abstract and normative. We have not looked at the Bankruptcy Code as it is actually implemented in bankruptcy practice. The record of bankruptcy courts has been mixed at best. Not only are the procedures wasteful, but the cases that should be the norm-cases in which the firm liquidates expeditiously or reorganizes successfully-are the exceptions. ${ }^{85}$ There are several reasons why bankruptcy procedure in practice falls short of the ideal. Bankruptcy proceedings involve bargaining among all the interested parties, and each can attempt to gain strategic advantages for his own benefit. ${ }^{86}$ More-

as See LoPucki, The Debtor in Full Control-Systems Failure Under Chapter 11 of the Bankruptcy Code? (pt. 1), 57 Aм. BANKR. L.J. 99, 100-01 (1983).

so Professor Roe's proposal, Roe, supra note 30 , at 559, that all investors in a reorganizing company receive common stock, the value of which is set by selling some shares in the market, is an effort to eliminate the conflicting incentives among those holding different kinds of ownership interests in the firm. See supra note 83. But one may not have to resort to the artificiality of an all-common-stock capital structure to avoid these conflicts. One could, for example, prohibit publicly-held companies from using the reorganization provisions of Chapter 11 and require them to liquidate under Chapter 7. If appropriate, the company could continue as a going concern under such a rule by setting up a new corporation and transferring to it all the assets of the old corporation. One could then sell the new 
over, most Chapter 11 petitions are filed by the managers of a corporation, who sometimes enter Chapter 11 not because it seems the best possible forum in which rights to the firm's assets can be adjudicated while simultaneously being preserved, but rather because it seems to be a way for them to preserve their jobs, at least for a time. ${ }^{87}$ Delay may also save something for the shareholders they represent, who are otherwise doomed. Petitions in bankruptcy are typically filed only moments before a secured creditor repossesses the firm's assets or the IRS levies on them. ${ }^{88}$ The managers are often literally only one step ahead of the sheriff. A Chapter 11 proceeding typically buys time for the managers, the shareholders, and other junior owners at the expense of the more senior ones. It is often only a way-station in a journey toward liquidation either under Chapter 7 or under state law. Indeed, even when the assets of the firm should be kept together, Chapter 11 provides a vehicle for delay, and advantage-taking, that could be avoided by a goingconcern sale of the assets. ${ }^{89}$ The costs most often are imposed on the secured creditors and perhaps the general creditors; the benefits almost always accrue to the shareholders and their managers.

Bankruptcy judges sometimes seem inclined to do little to remedy this state of affairs. A few seem to show either an inability or an unwillingness to comprehend the possibility that secured credit may be something more than a perverse and unfair creature of state law that should be thwarted at every turn..$^{80}$ Even more remarkable is their wonderful capacity for hope, their unshakeable faith that, given time, the firm's ship will come in. Often, bankruptcy judges seem to think that markets systematically undervalue firms that have filed petitions in bankruptcy. ${ }^{91} \mathrm{~A}$ bank-

company (stripped of all prepetition debt) to a third party or make a public offering (through an investment banker) of all the securities of that company. The proceeds of the sale or offering, which would be cash, could then be distributed to the original investors in accordance with their entitlements. Such a rule would largely eliminate the strategic use of current Chapter 11 practice, with its opportunities for voting, valuation, and plan manipulation.

${ }^{87}$ See Roe, supra note 30 , at 540-45.

8s See LoPucki, supra note 85, at 114-15. For an example of such a last-minute filing, see In re J.A. Thompson \& Son, Inc., 665 F.2d 941, 943-44 (9th Cir. 1982) (bankruptcy petition filed 20 minutes before secured creditor attempted to repossess the collateral).

89 See, e.g., In re Lionel Corp., 722 F.2d 1063 (2d Cir. 1983).

so See, e.g., Cowans, Uniform Commercial Code in Bankruptcy, in PRoceedngs of THE Fifth Seminar por Refereges in Bankruptcy 335, 337 (1968). The weaknesses of this view are explored supra note 52.

21 See, e.g., In re Nite Lite Inns, 17 Bankr. 367, 373 (Bankr. S.D. Cal. 1982) (court rejects, as an "artificial and unrealistic burden on any debtor attempting to reorganize," testimony to the effect that a bank would discount a note arising out of that reorganization 
ruptcy judge may insist that he, not the market, is the one best positioned to set a value on a firm in distress, even though year after year in case after case his valuations prove wildly inflated. ${ }^{\mathbf{2}}$ That the value of a secured creditor's rights turns both on the worth of the collateral and on the time at which the secured creditor can obtain payment has long been recognized as an integral part of the law of corporate reorganizations by federal judges and lawmakers. In discussing the rights of a secured creditor when a company is reorganized, Learned Hand noted in In re Murel Holding Corp. ${ }^{93}$ half a century ago:

It is plain that "adequate protection" must be completely compensatory; and that payment ten years hence is not generally the equivalent of payment now. Interest is indeed the common measure of the difference, but a creditor who fears the safety of his principal will scarcely be content with that; he wishes to get his money or at least his property. We see no reason to suppose that the statute was intended to deprive him of that in the interest of junior holders, unless by a substitute of the most indubitable equivalence. ${ }^{94}$

No one disputes that secured creditors must be protected from depreciation of the nominal value of their collateral while a Chapter 11 proceeding is in progress. ${ }^{95}$ Moreover, no one doubts that Congress understood and took account of the time value of money in enacting section 1129 (b) of the Bankruptcy Code, which repeats Judge Hand's notion of "indubitable equivalence" in dealing with the rights of secured creditors upon the implementation of a reorganization plan..$^{96}$ Nothing suggests that Congress suddenly failed

at $40 \%$ to $50 \%$ ). In a similar vein, the court in In re Atlas Pipeline Corp., 39 F. Supp. 846 , 848 (D. La. 1941) stated:

I am impressed that the views of the Commission are somewhat cold blooded and are based on the theory that no new security should be issued which is not worth, at the time, its face value. If the organization of a new enterprise was involved that view might be justified, but when you have a situation such as is presented here, where it is the duty of the court to try to protect the interests of all creditors as far as the assets and circumstances of the debtor permit, a more practical view should be taken.

"See Blum, The Law and Language of Corporate Reorganizations, 17 U. CHI. L. REv. 565, 577-78 \& n.18 (1950); see also Festerson, supra note 2, at 329; Trost, Corporate Bankruptcy Reorganizations: For the Benefit of Creditors or Stockholders?, 21 UCLA L. REv. $540,548-49$ (1973) (discussing examples of result-oriented valuations).

os 75 F.2d 941 (2d Cir. 1935).

* Id. at 942.

${ }^{96}$ See, e.g., In re South Village, Inc., 25 Bankr. 987, 994 (Bankr. D. Utah 1982).

2811 U.S.C. \$ 1129(b)(2)(A)(iii) (1982); see also SENATE REPORT, supra note 7, at 127, reprinted in 1978 U.S. CODE CONG. \& AD. NEWs 5787, 5913 ("The indubitable equivalent 
to understand the time value of money when it dealt with adequate protection in section 361 of the Bankruptcy Code, using again the term "indubitable equivalent," and noting repeatedly that the secured creditor must receive the "benefit of his bargain" during the pendency of a Chapter 11 proceeding. ${ }^{98}$

Moreover, Congress explicitly came to grips with the tendency of bankruptcy judges to undercompensate the secured creditor and overestimate a firm's chances of surviving as a going concern. The Bankruptcy Code provides that during the reorganization process the secured creditor cannot be forced to accept the promise of a first claim upon the firm's unsecured assets at the conclusion of the bankruptcy proceeding in exchange for his matured state-law right to repossess the firm's property. ${ }^{90}$ The bankruptcy judge must give the secured creditor who insists upon it a right in the here and now (such as a lien on specific assets, cash, or its "indubitable equivalent"), not pie in the sky.

The effect of this requirement is that a firm must either reach a deal by consent or provide specific protection. A firm without unencumbered assets, a ready source of cash, or anything else beyond a vision of a brighter future must persuade either the secured creditor or a third-party lender that the firm has value as a going concern. It may, of course, be difficult to make the case for keeping the assets intact, but it should not be more difficult in principle to persuade one out of many potential third-party lenders than it is to persuade any other neutral third party, judicial or otherwise. An inability to persuade anyone-other than a bankruptcy judge-that the firm should stay alive seems good evidence that it should not. Overvaluations by bankruptcy judges cause undercom-

language is intended to follow the strict approach taken by Judge Learned Hand in In Re Murel Holding Corp 75 F.2d 941 (2d Cir. 1935)."). This reasoning has been carried over to other parts of $\$ 1129$. See, e.g., In re Southern States Motor Inns, Inc., 709 F.2d 647 (11th Cir. 1983) (Under 11 U.S.C. $\$ 1129(a)(9)(C)$ (1982), "the interest rate to be used in computing present value of a claim . . . should be current market rate without any reduction for the 'rehabilitation aspects' of the plan.").

97 See 11 U.S.C. $\$ 361(3)$ (1982).

is See, e.g., Senate REPoRT, supra note 7, at 53, reprinted in 1978 U.S. Code Cong. \& AD. News 5787, 5839; House REPORT, supra note 7, at 339, reprinted in 1978 U.S. CoDE Cong. \& AD. News 5963, 6295.

- Section 361(3) of the Bankruptcy Code, 11 U.S.C. § 361(3) (1982), which allows other compensation "as will result in the realization by such entity of the indubitable equivalent of such entity's interest in such property," specifically excludes "compensation allowable under section 503(b)(1) [11 U.S.C. \& 503(b)(1) (1982)] of this title as an administrative expense," which is entitled to first priority. See SENATE REPORT, supra note 7, at 54, reprinted in 1978 U.S. CoDE CoNG. \& AD. NEws 5787, 5840 (observing that administrative expense priority "is too uncertain to be meaningful"). 
pensation of secured creditors. But the degree of undercompensation depends on the relative priority of the compensation received. ${ }^{100}$ Section 361 , accordingly, requires that relatively senior forms of compensation be used before a secured creditor can be kept in the picture involuntarily, and directly eliminates the most egregious forms of undercompensation. Even should it turn out that these limits on the ability of bankruptcy courts to choose the form of the protection they give to secured creditors prevent some desirable reorganizations from taking place, that consequence is no justification for giving secured creditors less than the value of their rights under state law. Without being disingenuous, one cannot rely on a provision designed to protect secured creditors from undercompensation to justify a policy-such as not protecting the time value of money-that must undercompensate them both in theory and in practice.

\section{Conclusion}

Junior classes, be they equity holders or unsecured creditors, resort to reorganization in bankruptcy because they want the opportunity to sort things out for their benefit and to capture any upside potential in giving their firm a future, however uncertain. The precise nature of that uncertainty is irrelevant, but if the choice between liquidation and reorganization of the firm is not to be skewed, the residual classes must pay for the opportunity they seek. Such a requirement does not violate any well-conceived notion of fairness or equity. After all, someone must bear the risk that the reorganized firm will fail. To insist that the residual class bear the burden by way of a rule that provides secured creditors with the value of their rights under state law does not prevent desirable reorganizations. To the contrary, it encourages junior owners to put the firm's assets to the use that the owners as a group would prefer.

We have not addressed in this article the wisdom of allowing secured creditors to be paid ahead of anyone else, because this question is not one peculiar to bankruptcy law. Although we would defend, and in fact have defended, ${ }^{101}$ the institution of secured credit as a general matter, the question is a difficult and complex one and we do not pretend to have the last word. ${ }^{102}$ Nothing in our

${ }^{100}$ See Note, Giving Substance to the Bonus Rule in Corporate Reorganizations: The Investment Value Doctrine Analogy, 84 YaLB L.J. 932, 936-39 (1975).

${ }^{101}$ See D. BAIRD \& T. JACKson, supra note 52, at 354-67.

${ }^{102}$ See supra note 52. 
argument, however, depends in the slightest on showing that secured credit is a good thing, for the argument would apply with equal force to any group given favored treatment under nonbankruptcy law. The desirability of secured credit-or other nonbankruptcy property rights-is ultimately not a bankruptcy question and attempting to transform it into one creates incentives that are perverse and counterproductive. 